\title{
9: 21984490-21957752
}

National Cancer Institute

\section{Source}

National Cancer Institute. 9: 21984490-21957752. NCI Thesaurus. Code C41939.

Physical location of CDKN2A_Gene 